\title{
EVALUATION OF A NEW TRANSPORT MEDIUM FOR THE PRESERVATION OF ORAL STREPTOCOCCI
}

\author{
B. B. Rundell, L. A. Thomson, W. J. Loesche* and H. M. Stiles \\ National Institute of Dental Research, National Institutes of Health, Bethesda, \\ Maryland 20014 and *University of Michigan School of Dentistry, Ann Arbor, \\ Michigan 48104, U.S.A.
}

\begin{abstract}
Summary-The survival of pooled plaque bacteria and a mixed suspension of Streptococcus mutans, Streptococcus sanguis, Streptococcus mitis, and Streptococcus salivarius were tested in three transport media. A new, non-nutritive, reduced transport fluid, RTF, was compared with VMG II and SBL, two recognized transport media. Specimens were stored in several vials of each medium and held at either $10^{\circ} \mathrm{C}$ or room temperature $\left(25^{\circ} \mathrm{C}\right)$. At time intervals over a 21 -day period, the number of viable colony-formingunits per $\mathrm{ml}$ in each vial was estimated by culture on mitis-salivarius agar. The survival of oral streptococci was enhanced by storage at $10^{\circ} \mathrm{C}$. VMG II and RTF performed equally well at this temperature. RTF maintained the most constant populations of streptococci with storage at room temperature. SBL was the least suitable medium for oral streptococci.
\end{abstract}

\section{INTRODUCTION}

AN IMPORTANT problem in the bacterial analysis of dental plaque has been the inability to transport specimens to the laboratory in a medium which preserves the viability of plaque flora without allowing the growth of any species. Various transport media for different types of specimens have been reported in the literature (PEIZER and StefFer, 1943; Alexander, 1952; Stuart, 1959; RingertZ, 1960; Cary and Blair, 1964; Møller, 1966; Gastrin, Kallings and Marcetic, 1968). It has been demonstrated conclusively that survival is generally favoured by a neutral, well-buffered environment which provides a low-oxygen tension and contains proper concentrations of certain inorganic ions (STUART, 1959).

MøLlER (1966) described a transport medium with four modifications (VMG I-IV) for the storage of endodontic specimens. He compared the survival of various strains of bacteria in VMG and Stuart's medium and demonstrated VMG to be superior. Møller reported that survival was affected by the age and number of cells in the specimen. He also observed that the viability of most strains was enhanced by storage at $24^{\circ}$ C. Jordan, Krasse and Møller (1968) tested the survival of "caries inducing" streptococci in dental plaque specimens which were stored in VMG II at room temperature. They proposed the use of VMG II as a transport medium for dental plaque specimens, because it preserved the viability of most plaque streptococci for several days. GASTRIN et al. (1968) formulated a modification of Stuart's medium designated SBL. They compared the survival of important clinical pathogens in Stuart, VMG IV, and SBL media. They concluded the VMG IV preserved specimens as well as the other 
two media, but promoted the growth of many strains tested. This work did not include an evaluation of common oral bacteria.

Recently, LoESCHE, HockeTT and SYED (1972) described a new medium for the transportation and dispersion of plaque specimens. This medium, designated as reduced transport fluid (RTF), differs from carlicr formulations in that it contains EDTA to enhance cell dispersion, and to eliminate possible toxic effects of trace heavy metal ions (BUTLer and KNIGHT, 1960; PostGate and HunTER, 1962). RTF medium contains dithiothreitol as a reducing agent. Dithiothreitol maintains a lower $\mathrm{Eh}$ and is less readily oxidized by air than reducing agents used in the other transport media (Cleland, 1964). No organic compounds capable of supporting microbial growth are present in RTF.

The survival of dental plaque flora from subjects with and without oral disease was evaluated in SBL, VMG II, and RTF transport media (SYED and LOESCHE, 1972). With strict anaerobic culturing conditions, periodontal plaque samples survived most successfully in RTF. Recoveries of organisms from carious plaque were higher with RTF and VMG II than SBL with usual anaerobic culturing methods.

The purpose of the present study was to compare SBL and VMG II with the new RTF medium described by LOESCHE et al. (1972) for the balanced survival of plaque flora at two storage temperatures. Observations were limited to the more frequently observed oral streptococci due to the relative ease in differentiating species on mitissalivarius agar, and the recent interest in the role of streptococci in dental caries.

\section{Transport media}

\section{MATERIALS AND METHODS}

VMG II was prepared according to MøLLER (1966).

SBL was prepared according to GASTRIN et al. (1968) with $0.8 \mathrm{~g}$ agar, the addition of $10 \mathrm{~g}$ of bacteriological charcoal, and the omission of methylene blue.

KTF: Solution 1. $0 \cdot 6$ per cent $\mathrm{K}_{2} \mathrm{HPO}_{4}$

Solution 2. 1.2 per cent $\mathrm{NaCl}$

$1 \cdot 2$ per cent $\left(\mathrm{NH}_{4}\right)_{2} \mathrm{SO}_{4}$

0.6 per cent $\mathrm{KH}_{2} \mathrm{PO}_{4}$

0.25 per cent $\mathrm{MgSO}_{4} .7 \mathrm{H}_{2} \mathrm{O}$

Solution 3. 0.1 M.Na EDTA (formula weight 416)

Solution 4. 1 per cent Dithiothreitol-store at $10^{\circ} \mathrm{C}$

Combine $75 \mathrm{ml}$ of solution $1,75 \mathrm{ml}$ of solution $2,10 \mathrm{ml}$ of solution 3 , and $20 \mathrm{ml}$ of solution 4 .

Dilute to 11 . with distilled water. Filter-sterilize using a membrane filter $(0.22-\mu \mathrm{m}$ pore size) and store at $10^{\circ} \mathrm{C}$ until use.

\section{Specimens}

One suspension of pooled plaque as well as one mixed suspension of four oral streptococci were evaluated in each of three transport media which were stored at $10^{\circ} \mathrm{C}$ and at $25^{\circ} \mathrm{C}$. Five replicate vials were prepared and sampled for each test condition. A total of 60 vials were tested.

Plaque samples from 10 individuals were pooled in distilled water and homogenized by sonication under an atmosphere of 95 per cent $\mathrm{N}_{2}-5$ per cent $\mathrm{CO}_{2}$. Aliquots of $0.1 \mathrm{ml}$ containing approximately $6 \times 10^{6}$ cells were dispensed in vials containing $3 \mathrm{ml}$ of transport medium. The same pooled plaque suspension was used to test all storage conditions.

Streptococcus mutans strain 6715, Strep. mitis ATCC strain 9811, Strep. sanguis ATCC strain 10558, and Strep. salivarius ATCC strain 9756 were individually cultivated in trypticase-yeast extract broth containing 0.01 per cent glucose (JoRdan, FITZGERALD and Bowler, 1960) for $24 \mathrm{hr}$ at $37^{\circ} \mathrm{C}$. Cells of each strain were then washed two times with physiological saline and suspended in distilled water with a cell ratio of 10:10:10:1, respectively, which represented an approximate total count of $5 \times 10^{8}$ cells $/ \mathrm{ml}$. 
Standard curves, which related plate counts of serial dilutions of each strain to optical density readings at $420 \mathrm{~nm}$ on a Gilford spectrophotometer were previously determined, to prepare this cell ratio in the mixed streptococcal suspension. Aliquots of $0.1 \mathrm{ml}$ were dispensed into vials of transport media, and stored at either $10^{\circ} \mathrm{C}$ or $25^{\circ} \mathrm{C}$ for the investigation period.

\section{Evaluation of survival}

Plate counts were made at intervals over a 21-day period to determine the viable colony forming units of each species per $\mathrm{ml}$ in each vial. Aliquots from all vials were serially diluted in 0.05 per cent yeast extract-distilled water to $10^{-5}$ and plated on mitis-salivarius agar. Plates were incubated anaerobically ( 95 per cent $\mathrm{N}_{2}-5$ per cent $\mathrm{CO}_{2}$ ) at $24 \mathrm{hr}$ at $37^{\circ} \mathrm{C}$ followed by $24 \mathrm{hr}$ of aerobic incubation at room temperature. The species were enumerated by observing colonial morphology under a dissecting microscope. For each test condition and time interval, five replicate vials were examined. The population in each vial was compared with the original mitis-salivarius population counted on the first day and expressed as $P_{i}{ }^{*}$, defined by the relation:

$$
\begin{gathered}
P_{i}^{*}=\frac{\text { Number of cells plated on day }(*)}{\text { Number of cells originally plated (Day 0) }} \\
i=\text { vial } 1-5
\end{gathered}
$$

The mean of these five rations, $\bar{p}^{*}$, was then computed and expressed as the percentage of the original sample:

The resultant percentages appear in Figs. 1-4 with prominent trends described under Results. A semilogarithmic axis was chosen to plot the data. This method represents equal factors of increase and decline of population with equal graphical increments.

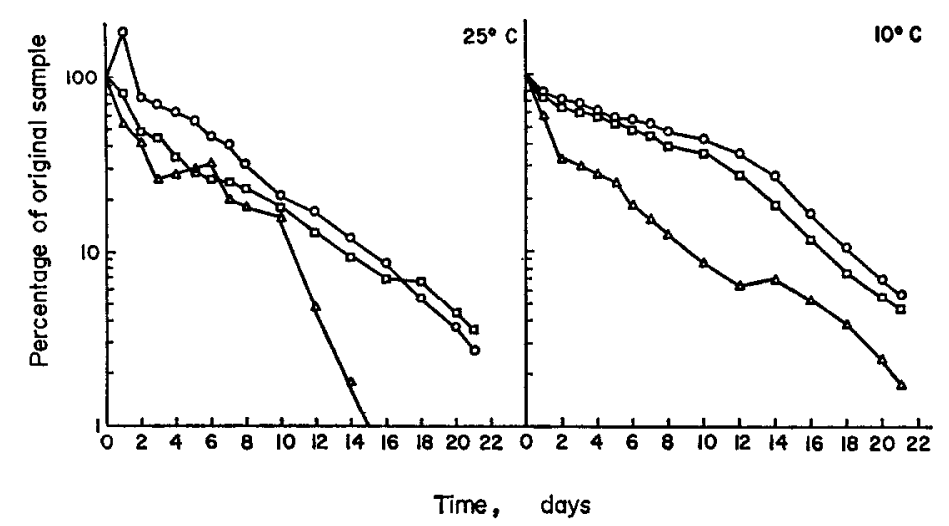

FIG. 1. Survival of pooled plaque bacteria at $25^{\circ} \mathrm{C}$ and $10^{\circ} \mathrm{C} . \bigcirc$ VMG II, $\square$ RTF, $\triangle$ SBL.

\section{Variability in sampling}

For each test condition and time interval, the standard deviation $(S)$ was computed as:

$$
S=\sqrt{\frac{\sum_{i=1}^{5}\left(P_{t}^{*}-\bar{p}^{*}\right)^{2}}{4}}
$$




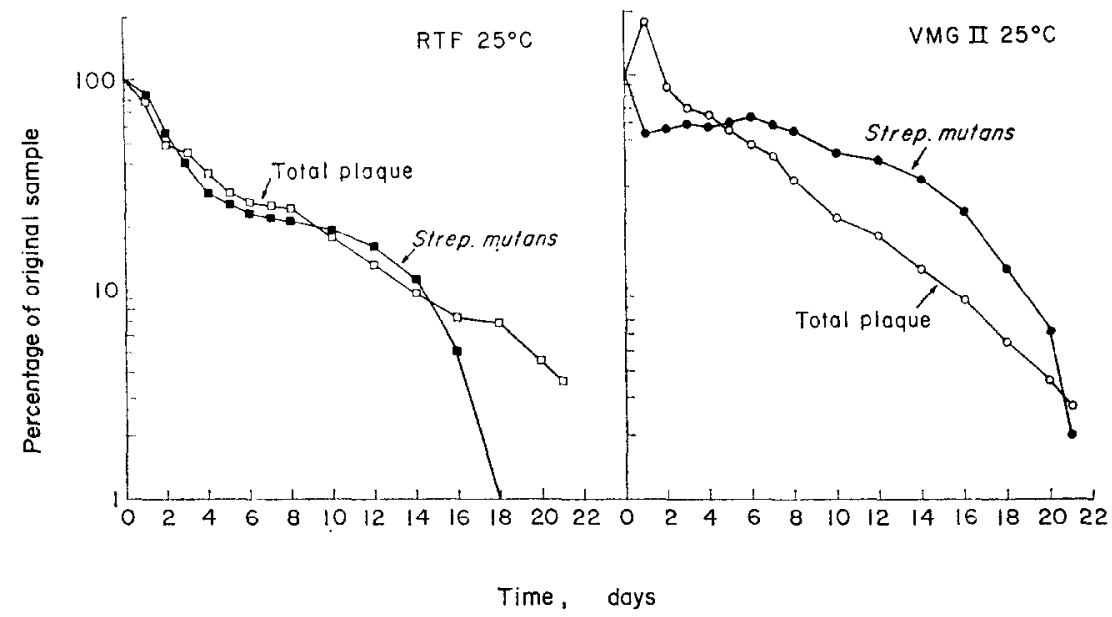

Fig. 2. Survival of Strep. mutans within pooled plaque at $25^{\circ} \mathrm{C}$. $\square$ Total plaque RTF, Total plaque VMG II, Itrep. mutans RTF, Strep. mutans VMG II.

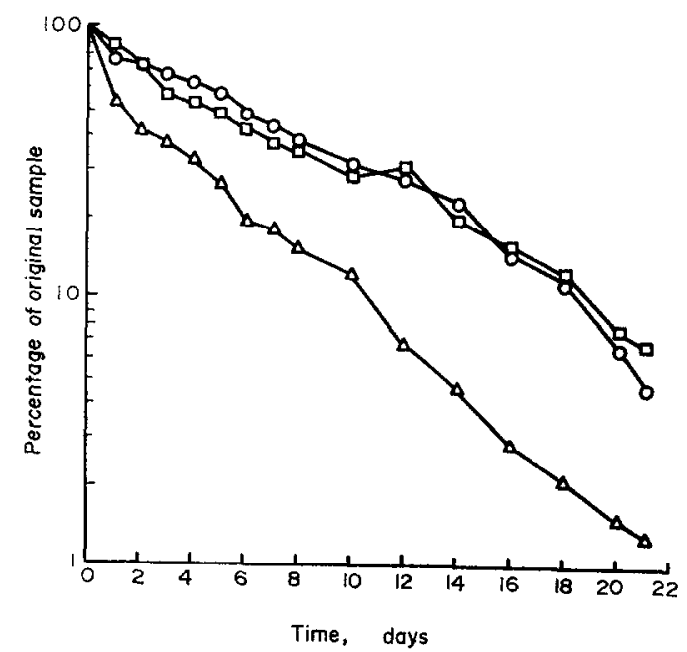

Fiv. 3. Survival of Strep. mutans within pooled plaque at $10^{\circ} \mathrm{C}$. $\bigcirc$ VMG II, $\square$ RTF, $\triangle \mathrm{SBL}$.

\section{RESULTS}

Figure 1 indicates the survival of plaque flora enumerated on mitis-salivarius agar with storage at room temperature $\left(25^{\circ} \mathrm{C}\right)$ and $10^{\circ} \mathrm{C}$. At $25^{\circ} \mathrm{C}$, VMG II permitted almost a doubling of population during the first day. In contrast, with RTF no growth was observed. Survival was least favourable in SBL. This observation with SBL was consistent throughout this study. With storage at $10^{\circ} \mathrm{C}$, no evidence of increase in colony forming units was noted. Decreases in viable colony-forming units were more gradual in all three media at this temperature. With regard to streptococci, this result 


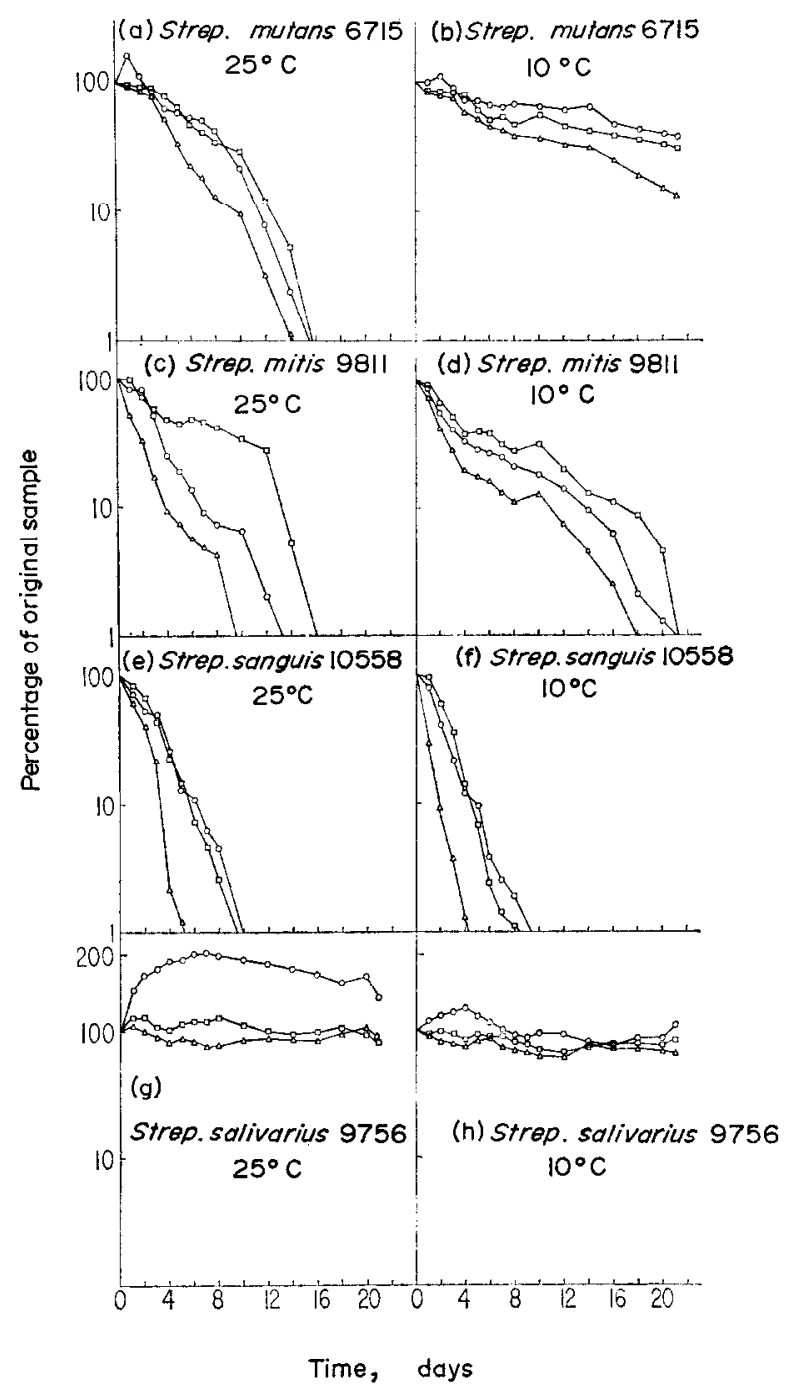

FIg. 4. Survival of strains in a mixed Streptococcal Suspension at $25^{\circ} \mathrm{C}$ and $10^{\circ} \mathrm{C}$.

O VMG II, $\square$ RTF, $\triangle$ SBL.

conflicts with data presented by MøLleR (1966) with Group A streptococci, but is in agreement with observations made by BALLANTYNE (1930).

Figure 2 compares the survival of Strep. mutans within pooled plaque with the survival of plaque flora in RTF and VMG II at $25^{\circ} \mathrm{C}$. The survival curve for Strep. mutans is similar to the curve representing plaque flora in RTF. However, the comparable curves for VMG II were dissimilar. Figure 3 shows that Strep. mutans in plaque survived equally well in RTF and VMG II when stored at $10^{\circ} \mathrm{C}$.

As a separate experiment, a suspension of four oral streptococci was stored in transport media to monitor the interaction and survival of specific strains over a time 
period. Results supported the previous conclusion that the preservation of streptococci is favoured by storage at $10^{\circ} \mathrm{C}$. Figures $4 \mathrm{a}$ and $4 \mathrm{~b}$ indicate that Strep. mutans 6715 survived equally well in VMG II and RTF at $10^{\circ} \mathrm{C}$, while VMG II permitted an increase in colony forming units at $25^{\circ} \mathrm{C}$. Figures $4 \mathrm{c}$ and $4 \mathrm{~d}$ illustrate that the viability of Strep. mitis ATCC 9811 was best maintained in RTF at either storage temperature. Strep. salivarius ATCC 9756 was the most hardy strain tested. Figures $4 \mathrm{~g}$ and 4h show that SBL and RTF maintained constant survival of this organism throughout the 21-day period. In VMG II, however, some increase in colony-forming units occurred. This was true at both storage temperatures.

Variability in the enumeration of survivors was determined by computing the standard deviation for each point plotted in Figs. 1-4. Calculated variabilities were less than \pm 16 per cent with the exception of Strep. mutans in pooled plaque in VMG II and RTF at $10^{\circ} \mathrm{C}$. For these two tests, the maximum standard deviations were \pm 24 per cent and \pm 31 per cent respectively. No variability was computed for ATCC strain 9756 (Strep. salivarius), because the initial number of colony-forming units counted was so small that apparent variability was excessive.

Therefore, colony counts on all five plates were considered as one population to determine each point on the graphs for this strain.

\section{DISCUSSION}

One difficulty in the evaluation of cell survival was the detection of changes in cell counts that were not due to multiplication or death under normal storage conditions. Repeated agitation and sampling of the vials over time might have caused selective death of some organisms. De-aggregation and re-aggregation of cells may have also occurred. The data demonstrate differences among the three media, in their abilities to maintain constant bacterial populations as well as to preserve viability.

In this study, SBL was the least suitable transport medium for oral streptococci, because it allowed the most rapid decreases in viable colony-forming units under the storage conditions tested. The rise in the number of plaque bacteria in VMG II at $25^{\circ} \mathrm{C}$ is undesirable. Apparently in the first 6 days of storage, bacteria other than Strep. mutans were growing, whereas with longer storage, these bacteria died. This resulted in a disproportionately high recovery of Strep. mutans. Growth in VMG II was probably permitted by the presence of nutrients in the medium and the inability of the bacteriostatic agent, phenylmercuric acetate, to inhibit growth of all bacteria to the same extent. Evidence of microbial growth in VMG II was also noted by SYED and LOESCHE (1972).

In this investigation, death of the cells usually ensued at a slower rate in all three media when stored at $10^{\circ} \mathrm{C}$. This strongly suggests that samples shoult be refrigerated as soon as possible following collection. If samples must remain at rovni temperature, RTF appears to be the best choice of medium to preserve the original proportions of various strains of streptococci. RTF has the additional advantage of being quick and easy to prepare. This might be an important factor if one does not have access to extensive laboratory facilities.

The conclusions drawn from this study are: (1) SBL is the least suitable medium 
for transportation and storage of oral streptococci; (2) the survival of oral streptococci is enhanced by storage at $10^{\circ} \mathrm{C}$. VMG II and RTF perform equally well at this temperature; and (3) RTF maintains the most constant population of streptococci with storage at room temperature. Although additional work is needed to see how other oral bacteria survive in RTF, its use in quantitative studies involving oral streptococci should be considered.

Résumé-On a vérifié la survivance des bactéries de la plaque, mises en commun, et une suspension mixte de Streptococcus mutans, Streptococcus sanguis, Streptococcus mitis, et Streptococcus salivarius dans trois milieux de transport. On a comparé un nouveau fluide de transport réduit, non-nutritif, le RTF avec le VMG II et le SBL, deux milieux de transport reconnus. Les échantillons ont été stockés dans plusieurs ampoules pour chaque milieu et gardés ou à $10^{\circ} \mathrm{C}$ ou à la température de la chambre $\left(25^{\circ} \mathrm{C}\right)$. A d'intervalles de temps, sur une période de 21 jours, on a évalué par culture sur agar mitis salivarius, le nombre d'unités de streptocoques oraux viables, formant des colonies, par ml. dans chaque ampoule. La survivance des streptocoques oraux a été rehaussée par stockage à $10^{\circ} \mathrm{C}$. Le MG II et le RTF se sont comporté également bien à cette température. Le RTF maintint les plus constantes populations de streptocoques avec le stockage à la température de la chambre. Le SBL était le milieu le moins convenable pour les streptocoques oraux.

Zusammenfassung-Es wurde das Überleben von angesammelten Plaquebakterien und eine Suspensionsmischung von Streptococcus mutans, Streptococcus sanguis, Streptococcus mitis und Streptococcus salivarius in drei Transportmitteln untersucht. Es wurde eine neue, nicht nahrhafte, reduzierte Transportflüssigkeit, RTF, mit zwei anerkannten Transportmitteln, VMG II und SBL verglichen. Es wurden Proben von jedem Mittel in mehreren Phiolen aufbewahrt und entweder bei $10^{\circ} \mathrm{C}$ oder Raumtemperatur $\left(25^{\circ} \mathrm{C}\right)$ gehalten. Für eine Dauer von über 21 Tagen wurde in Zeitabständen die Zahl der lebensfähigen, Kolonie bildenden Einheiten pro $\mathrm{ml}$ in jeder Phiole mittels Kultur auf Mitis-salivarius Agar geschätzt. Das Ǔberleben der oralen Streptococci wurde durch Lagerung bei $10^{\circ} \mathrm{C}$ begünstigt. VMG II und RTF erwiesen sich ebenso günstig bei dieser Temperatur. RTF unterhielt die konstantesten Bevölkerungen der Streptococci bei Lagerung in Raumtemperatur. SBL war das ungeeignetste Mittel für orale Streptococci.

\section{REFERENCES}

AleXANDER, J. G. 1952. A transport medium for gynaecological swabs. Obst. Gynaec. Br. Emp. 59, 246-251.

BallaNTYNe, E. N. 1930. On certain factors influencing the survival of bacteria in water and saline solutions. J. Bact. 19, 303-320.

Butler, M. and KNight, B. C. J. G. 1960. The survival of washed suspensions of mycoplasma. J. gen. Microbiol. 22, 470-477.

CARY, S. G. and Blair, E. B. 1964. New transport medium for shipment of clinical specimens. J. Bact. 88, 96-98.

Cleland, W. W. 1964. Dithiothreitol, a new protective reagent for SH groups. Biochemistry 3, $480-482$.

Gastrin, B., Kallings, L. O. and Marcetic, A. 1968. The survival time for different bacteria in various transport media. Acta path. microbiol. scand. 74, 371-380.

Jordan, H. V., Fitzgerald, R. J. and Bowler, A. E. 1960. Inhibition of experimental carics by sodium metabisulfite and its effect on the growth and metabolism of selected bacteria. J. dent. Res. 39, 116-123.

Jordan, H. V., Krasse, B. and Møller, A. 1968. A method for sampling human dental plaque for certain caries inducing streptococci. Archs oral Biol. 13, 919-927.

LoESCHE, W. J., HoCKETT, R. N. and SYED, S. 1972. The predominant cultivable flora of tooth surface plaque removed from institutionalized subjects. Archs oral Biol. 17, 1311-1325. 
Møller, J. R. A. 1966. Microbiological Examination of Root Canals and Periapical Tissues of Human Teeth. Akademiforlaget-Goteborg, Goteborg, Sweden.

Peizer, L. and Steffen, G. 1943. Improved method of transportation of material from gonococcal infections. J. Lab. clin. Med. 28, 1121-1126.

Postgate, J. R. and Hunter, J. R. 1962. The survival of starved bacteria. J. gen. Microbiol. 29, 233-263.

RingerTz, O. 1960. A modified Stuart medium for the transport of gonococcal specimens. Acta path. microbiol. scand. 48, 105-112.

StuarT, R. D. 1959. Transport medium for specimens in public health bacteriology. Publ. Hlth Rep., Wash. 74, 431-438.

SYED, S. A. and LOESCHE, W. J. 1972. Survival of human dental plaque flora in various transport media. Appl. Microbiol. 24, 638-644. 